\title{
JOKES AS THE SOURCE OF STUDY STEREOTYPIC IMAGE OF REGION (ON AN EXAMPLE OF JOKES ABOUT SIBERIA) ${ }^{1}$
}

\author{
Olga N. Kondratyeva \\ Kemerovo State University, Kemerovo, Russia
}

\begin{abstract}
The humorous discourse is considered an important source of stereotypic images of the Russian regions. As it reflects territorial peculiarities and their inhabitants, reveals the attitude to various regions in the society, the linguistic analysis of regional stereotypes should become a starting point in the further formation of brands and images of regions. The jokes about Siberia are analyzed in the article and the stereotypic image of this region is reconstructed. Being based on content analysis and a framing method the study is aimed at presenting stereotypes about Siberia in the form of frames (knowledge structures) and their constituents (sub-frames and slots). It is stated that the stereotypic image of Siberia looks quiescent; the jokes reflect a deeply rooted conception of Siberia by residents of other regions of Russia and foreigners as a distant, huge area with severe climatic conditions, rich in natural resources, and an exile place of immigrants who are busy with hard work. Currently Siberia has got another stereotype and is perceived as an object of claims of some boarding countries. The stereotypic image of Siberia is depressive; the majority of regional characteristics that are reflected in jokes convey general negative comprehension. The revealed stereotypes point to necessity of creating a positive image of Siberia.

Key words: image, region, Siberia, stereotype, joke, image studies, lexis, humoristic discourse.

Citation. Kondratyeva O.N. Jokes as the Source of Study Stereotypic Image of Region (On an Example of Jokes About Siberia). Vestnik Volgogradskogo gosudarstvennogo universiteta. Seriya 2. Yazykoznanie [Science Journal of Volgograd State University. Linguistics], 2019, vol. 18, no. 3, pp. 140-149. (in Russian). DOI: https:// doi.org/10.15688/jvolsu2.2019.3.11
\end{abstract}

УДК 81 '0:82-36

Дата поступления статьи: 26.01.2019

ББК 81.055 Дата принятия статьи: 05.06.2019

\section{АНЕКДОТЫ КАК ИСТОЧНИК ИЗУЧЕНИЯ СТЕРЕОТИПНОГО ОБРАЗА РЕГИОНА (НА ПРИМЕРЕ АНЕКДОТОВ О СИБИРИ) ${ }^{1}$}

\author{
Ольга Николаевна Кондратьева \\ Кемеровский государственный университет, г. Кемерово, Россия
}

\begin{abstract}
Аннотация. Юмористический дискурс является важным источником изучения стереотипных образов регионов разных стран, фиксирующим наиболее значимые особенности территорий с их населением и эксплицирующим отношение к регионам в обществе. Поэтому лингвистическое изучение региональных стереотипов должно стать отправной точкой в дальнейшем целенаправленном формировании брендов и - имиджа российских регионов. В статье анализируются анекдоты о Сибири и реконструируется ее стереотип근 ный образ. Основными методами исследования послужили контент-анализ и фреймовый анализ, заключающийся в представлении содержащейся в анекдотах стереотипной информации в виде фреймов (структур знаний) и их составляющих - субфреймов и слотов. В статье показано, что стереотипный образ Сибири в анекдотах статичен, поскольку они отражают традиционные, укоренившиеся в сознании жителей других регионов России и иностранцев представления о ней как о далеком огромном крае с суровыми климатическими условиями, богатом природными ресурсами, ставшим местом ссылки и тяжелого труда переселенцев. Выявлено, что новым стереотипным признаком стало восприятие Сибири как объекта притязаний других стран. Образ этого региона, созданный в анекдотах, депрессивен: большинство его характеристик имеет ярко
\end{abstract}


выраженный негативный характер. Результаты исследования могут быть использованы в работе по созданию позитивного имиджа Сибири.

Ключевые слова: образ, регион, Сибирь, стереотип, анекдот, имиджелогия, лексика, юмористический дискурс.

Цитирование. Кондратьева О. Н. Анекдоты как источник изучения стереотипного образа региона (на примере анекдотов о Сибири) // Вестник Волгоградского государственного университета. Серия 2, Языкознание. - 2019. - Т. 18, № 3. - С. 140-149. - DOI: https://doi.org/10.15688/jvolsu2.2019.3.11

\section{Введение}

Описание образов регионов России является одним из значимых направлений исследований в современной лингвистике, поскольку в настоящее время «необходимость конструирования и трансляции положительного образа территории осознана на официальном уровне и ставится как политическая задача в российских регионах и на общероссийском уровне» [Печищев, 2007, с. 201]. Результатом целенаправленно и грамотно созданного образа региона станет его общественно-политическая, культурно-историческая и инвестиционная привлекательность.

Описания образов территорий (стран и регионов) выполняются преимущественно на материале масс-медиа, социальных сетей или блогосферы, то есть объектом исследования до сих пор становились в основном медиаобразы регионов, являющиеся в некоторой степени искусственными образованиями. Однако, по нашему мнению, любую деятельность по созданию имиджа региона необходимо начинать с изучения образа региона, сформировавшегося в сознании жителей страны, с выявления связанных с конкретной территорией мифов и стереотипов [Кондратьева, Фролова, 2018, с. 80].

Существуют различные методы их определения, например, непосредственный опрос информантов или анализ существующих в культуре суждений об особенностях той или иной области и населяющих ее жителей. Однако, как отмечают Е.Я. Шмелева и А.Д. Шмелев, «ориентация на эксплицитные суждения носителей культуры может вводить в заблуждение, поскольку значительное число стереотипов не вполне осознаются их носителями и потому не эксплицируются, и, напротив, в наличии какихто стереотипов их носитель может не желать признаваться» [Шмелева, Шмелев, 2014, c. 167]. Поэтому для установления территори- альных стереотипов должны использоваться методы, ориентированные на выявление имплицитных стереотипов, стоящих за высказываниями представителей соответствующей лингвокультуры. Одним из наиболее эффективных методов может стать изучение анекдотов, посвященных отдельной территории и ее жителям.

Тем не менее до настоящего момента попыток исследования территориальных стереотипов с опорой на материал анекдотов предпринято не было, хотя существует и результативно используется аналогичная методика для изучения этнических стереотипов (см., например: [Абильдинова, 2008; Бартминьский, 2009; Жерновая, 2011; Собянина, 2018; Тер-Минасова, 2000; Шмелева, Шмелев, 2014; и др.]).

Следует отметить, что этнические стереотипы характеризуют этнос в целом (см.: [Крысько, 2008; Lippman, 1922; Quasthoff, 1973]), в то время как на территории ряда государств (особенно столь крупных, как Россия) представители одного этноса, в зависимости от места проживания, могут обладать дополнительными специфическими характеристиками. Соответственно, уместно говорить о существовании региональных (например, связанных с Сибирью, Уралом, Дальним Востоком и их жителями) и городских стереотипов (например, связанных с г. Москвой, Санкт-Петербургом и их жителями).

Поскольку стереотипные особенности регионов далеко не всегда совпадают, специфические черты (как правило, представленные в преувеличенном виде) часто интерпретируются как отклонение от стандарта и поэтому считаются смешными, глупыми. Следовательно, именно наиболее характерные черты территорий становятся объектами юмористического осмысления, что и позволяет эксплицировать стереотипный образ региона в процессе анализа анекдотов. 


\section{РАЗВИТИЕ И ФУНКЦИОНИРОВАНИЕ РУССКОГО ЯЗЫКА}

В данный момент проблема изучения стереотипных образов регионов, бытующих в юмористическом дискурсе, остается открытой и апробация методики их исследования является одной из наиболее актуальных задач лингвистики и имиджелогии.

Материалом изучения являются анекдоты о Сибири (139 анекдотов), размещенные на сайтах Анекдоты из России, Мир анекдотов, Анекдотов.net. Основными методами исследования послужили контент-анализ и фреймовый анализ, заключающийся в представлении содержащейся в анекдотах стереотипной информации о данном регионе в виде фреймов (структур знаний) и их составляющих - субфреймов и слотов (см., например: [Маленова, Терских, 2015; Сушненкова, 2011; и др.]).

\section{Результаты исследования и их интерпретация}

В процессе анализа российских анекдотов установлено, что в юмористическом дискурсе структуру стереотипного медиаобраза Сибири формируют фреймы «Природа и география», «История», «Экономика», «Социальная сфера», «Население».

\section{1. Фрейм «ПРИРОДА И ГЕОГРАФИЯ»}

Наиболее часто в юмористическом дискурсе характеристика рассматриваемого региона осуществляется посредством акцентирования внимания на его географических, природных и климатических особенностях, предстающих в анекдотах в гипертрофированном виде.

Субфрейм 1.1. «Характеристики территории». В рамках данного фрейма в российских анекдотах объектом юмористической рефлексии становится географическое положение региона, его удаленность от административного центра России и других стран, большая площадь, непривлекательность для жителей и туристов.

Слот 1.1.1. «Большая площадь территории». Одной из значимых характеристик Сибири, плотно укоренившейся в сознании россиян, является ее огромная площадь. Если в медиадискурсе подобные стереотипные представления репрезентируются лексемами боль- шой, огромный, бескрайний и др., то в анекдотах для указания на крупные размеры Сибири используется сопоставление с размерами европейских стран или гиперболизированное указание на количество китайцев, способных затеряться на столь большой территории:

(1) - Да одна наша Сибирь - это пять Франций! - Весь мир настораживает, что вы меряете свою территорию другими странами.

(2) После совместных учений России, Китая и Индии на территории Сибири потерялась рота китайцев - два миллиона человек.

Слот 1.1.2. «Удаленность территоpuи». В анекдотах акцентируется внимание на удаленности Сибири и от Москвы, и от всего мира. Репрезентантами подобной характеристики региона являются лексемы и сочетания далеко, далекий, конец мира, край света, Тьмутаракань, у черта на куличках и др.:

(3) Времена застоя. Распределили одного студента к черту на кулички, то есть в Сибирь. Добирался он месяц. Оставшееся расстояние надо было лететь на вертолете, так как другой транспорт не ходил. Короче, повезли мужика на вертолете. Добрались до места, высота 200 метров. Пилот говорит: «Прыгай!». Студент: «Вы что, охренели? Я же разобьюсь, спуститесь пониже». Пилот: «Сейчас, размечтался. В прошлый раз спустились: один спрыгнул, двое запрыгнули».

Слот 1.1.3. «Непривлекательность региона для проживания и отдыха». Удаленность и суровые климатические условия предопределяют формирование стереотипного восприятия Сибири как места, непривлекательного для постоянного проживания, отдыха и туризма.

В анекдоте (3) отражено желание жителей региона покинуть его при первой же возможности (ср.: ...Пилот: «Сейчас, размечтался. В прошлый раз спустились: один спрыгнул, двое запрыгнули»). Стремление избегать посещения Сибири также становится в российских анекдотах регулярным поводом для комизации:

(4) Женщина - как мир. В 20 лет она как Африка - мало изучена. В 30 лет она как Индия - мягкая и теплая. В 40 лет она как Америка-технически совершенная. В 50 лет - как Европа, вся в руинах. 
В 60 лет - как Сибирь. Все знают, где это, но никто не хочет идти.

(5) - А Вы бывали в Сибири?

- Я живу тихо, скромно и незаметно, чтобы никогда не видеть Сибирь...

Отдых в Сибири в юмористическом дискурсе зачастую становится эвфемизмом крупных политических неудач, устойчиво ассоциируясь с судебным приговором и ссылкой:

(6) Как сообщили в следственном комитете, на днях Сергею Удальцову предложат совершить экскурсию по Ленинским мемориальным местам. Основной маршрут - Сибирь, Шушенское. В окружении Удальцова рассматривают альтернативные варианты экскурсии: шалаш в Разливе или Лондон Цюрих.

(7) Когда Прохорову пришло по электронной почте письмо с рекламой отдыха в Сибири, то он долго думал, что это: обычный спам или намек на результаты выборов.

Субфрейм 1.2. «Климат». Сибирь традиционно считается одним из самых холодных мест в мире, своеобразным царством мороза, холода, льда и снега, что и определяет высокую частотность данного фрейма в юмористическом дискурсе.

Слот 1.2.1. «Мороз и холод». Стереотипные представления создают образ Сибири как региона с аномально низкими температурами, где мороз и холод характерны не только для зимы, но и для остальных времен года. Репрезентанты этих представлений в анекдотах холод, холодно, мороз, крещценский мороз, морозная свежесть, замерзать, оттаять, вечная мерзлота и др.:

(8) Живем мы в Сибири. Зимы у нас холодные, девчонки по две пары стрингов надевают!

(9) - Привет из Сибири! - Фу, дефис вместо длинного тире! - Это от холода!

(10) Кого-то еще в Сибири выводит из себя реклама жевательной резинки со вкусом морозной свежести?

(11) Лучшая охранная система для машины в России - «Крещенский мороз-2006», доказано в Сибири.

Одной их характерных особенностей анекдотов является регулярное подчеркивание аномальных температур, характерных для Сибири:
(12) На улице погода -30. Посмотрю, думаю, какая погода у друга в Сибири, смотрю-а там -60. Звоню к нему:

- Привет, какая там у вас температура?

- Да ничего, нормально, -30.

- Тю, а я вот на сайте смотрю, -60.

- Так то на улице!

(13) Слушает мужик прогноз погоды. Передают «В Сибири минус 45 градусов». Не поверил мужик, звонит своему другу в Сибирь:

- Слушай, у вас там, говорят, холодина жуткая?

- Да нет, минус 20 - минус 25.

- Да? А по телику сказали, что минус 45.

- А ты сложи!

Соответственно, погода при температуре ниже 20 градусов воспринимается жителями региона как теплая:

(14) - Привет! У нас -7, снег валит вовсю, сугробы и настоящая зима.

- У нас в Сибири -19, снег валит два дня, сугробы с ноября лежат - все радуются теплу и весне.

(15) Понял, что я настоящий сибиряк, когда, просматривая прогноз погоды и видя минимум -25, невольно поймал себя на мысли «тепло...».

Слот 1.2.2. «Снег и лед». Низкие температуры Сибири закономерно приводят к тому, что вода на данной территории трансформируется в снег и лед, которые в юмористическом дискурсе становятся специфическими круглогодичными характеристиками региона. Наиболее частотные репрезентанты названных стереотипных представлений снег, сугробы, метель, лед, каток и др.:

(16) Зима в Сибири в этом году выдалась особенно снежной. Но дворники этому только рады: никогда еще не вытаивало столько потерянных денег, пустых бутылок, и, что самое главное, Дедов Морозов с вполне свежими подарками.

(17) В Америке престижно иметь во дворе большой бассейн. В Сибири состоятельные люди тоже строят возле своего дома бассейны. Только там прижилось название не бассейн, а каток.

Слот 1.2.3. «Времена года». В анекдотах регулярно акцентируется внимание на повышенной продолжительности сибирской зимы, весна и осень в стереотипном образе Сибири не представлены: 


\section{РАЗВИТИЕ И ФУНКЦИОНИРОВАНИЕ РУССКОГО ЯЗЫКА}

(18) В Сибири 9 месяцев зима, а остальное лето, лето.

(19) Сибирь, реклама... «Попробуй!!! Выдержи зимУ: НОЯБРЬ!!! ДЕКАБРЬ!!! ЯНВАРЬ И ФЕВРАЛЬ!!! И получи дополнительно БОНУС!!! MAPT!!!»

Сибирское лето, согласно стереотипным представлениям, отраженным в юмористическом дискурсе, является исключительно холодным и дождливым либо максимально коротким (один день):

(20) В Библии написано, что дождь шел 40 дней и 40 ночей. Они назвали это страшной катастрофой. В Сибири это называется лето.

(21) У нас в Сибири два праздника: Новый год и лето. Оба длятся одинаково.

(22) - Мужчина, Вы почему такой незагорелый?

- Я из Сибири.

- А что у вас там лета нет?

- Есть, но я в тот день был на работе.

(23) Лето в Сибири очень жаркое, главное, не пропустить этот день.

Субфрейм 1.3. «Фауна». Территория Сибири предстает в анекдотах плотно заселенной животными, среди которых наиболее распространены медведи и волки, передвигающиеся непосредственно по улицам городов и деревень и нападающие на людей:

(24) Мой дед, когда в Сибири жил, на медведя в тайгу ходил с голыми руками, он мне писал об этом. Ну как писал, диктовал кому-то.

(25) Замечено: лучшие биатлонисты из России - выходцы из Сибири, потому что волки не прощают ошибок ни в стрельбе, ни в беге.

(26) «Волки у нас цивилизованные», - говорят сибиряки, - «Почтальона сожрут, а почту не тронуп».

\section{2. Фрейм «ИСТОРИЯ»}

В юмористическом дискурсе о Сибири регулярно встречаются отсылки к историческим событиям, оказавшим существенное влияние на формирование образа региона, и персонажам, связанным в сознании россиян с Сибирью.

Субфрейм 2.1. «Место миграции». Значимым компонентом стереотипного образа Сибири является представление о данном регионе как месте, в котором с давних времен над коренным населением доминировали переселенцы (вынужденные или добровольные) из других районов России.

Слот 2.1.1. «Место ссылки». Несмотря на то что с 80-х гг. ХХ в. Сибирь уже официально не является местом ссылки, до сих пор эти стереотипы активно эксплуатируются в анекдотах. К репрезентантам таких стереотипных представлений относятся лексемы сослать, ссылка, каторга, сидеть и др.:

(27) Жена - мужу: Если тебя сошлют в Сибирь, я, конечно, пойду вместе с тобой, но шубу надо бы купить заранее.

(28) - Папа, ты в школьные годы тоже на «камчатке» сидел?

\section{- Нет, в Сибири.}

(29) Она поехала за ним в Сибирь и испортила ему всю каторгу.

Наиболее часто комический эффект создается за счет использования лексемы cсылка, в частности столкновения значений 'наказание посредством насильственного переселения в отдаленный регион', 'место такого пребывания' и 'указание на страницу в Интернете' :

(30) Раньше известность человека определялась количеством ссылок в Сибирь, сегодня - в Интернете.

(31) Для получения детальной информации о природе Сибири воспользуйтесь ссылкой.

(32) - Вот в статье говорят о том, что раньше было лучше.

- Ага, и трава зеленее, и деревья выше. И ссылки-ссылочнее. Сибирь.

- Они не были реферальными. Они были в

Слот 2.1.2. «Место переселения». Рост сибирского населения также традиционно связывается в анекдотах с переселением народов (как в сталинский период, так и в новое время). Репрезентантами данного слота являются лексемы отправить, переселить, переселение, депортировать, депортачия, колонизировать, колония, миграция, эвакуаџия.

(33) Хватит уже чернить нашу историю и говорить, что в 1917 году людей выбрасывали из квартир и усадеб, отправляя в Сибирь! Это просто была программа реновации. И с тех пор она повторяется раз в сто лет. 
(34) Говорят, Рамзан Ахмадович собирается стать новым российским Сталиным? Ага, чтобы выслать всех грузин в Сибирь!

Субфрейм 2.2. «Исторические личности». В юмористическом дискурсе встречаются упоминания об исторических личностях, биография которых связана с Сибирью. Это прежде всего декабристы, Ленин, Хабаров.

(35) А знаете ли вы, что декабристы писали из Сибири царю прошения с текстом: «Зацени мою ссылку!», а Николай I отмечал ссылку как понравившуюся.

(36) Каксобшщли в следственном комитете, на днях Сергею Удальцову предложат совершить экскурсию по Ленинским мемориальным местам. Основной маршрут - Сибирь, Шушенское. В окружении Удальцова рассматривают альтернативные варианты экскурсии: шалаш в Разливе или Лондон -Цюрих.

\section{3. Фрейм «ЭКОНОМИКА»}

Экономика Сибири предстает в юмористическом дискурсе как исключительно экспортно-сырьевая. Производственная и сельскохозяйственная сферы, значимые для экономического развития региона, практически не отражены в анекдотах.

Субфрейм 3.1. «Природные ресурсы». Сибирь традиционно считается крупнейшим в России сырьевым центром, в котором сконцентрированы богатые природные ресурсы и полезные ископаемые.

Слот 3.1.1. "Сибирь как ресурсный центр, источник благосостояния». Длительное время регион воспринимался как сырьевой придаток страны, из которого все богатства перекачивались в столицу и распределялись по всей стране, теперь же эти ресурсы воспринимаются как достояние олигархов, источник их благосостояния, что и зафиксировано в российских анекдотах. Подобные стереотипные представления эксплицированы сочетаниями сырьевой придаток, сырьевая колония. В пределах рассматриваемого фрейма для репрезентации ресурсных стереотипов также используются комические приемы трансформации прецедентных текстов и вольной расшифровки аббревиатур:

(37) Ошибся Ломоносов: кто-то другой, а не Россия прирастает могуществом Сибири.
(38) - Слушай, а из-за чего вся эта возня вокруг ЮКОСа началась?

- Да наверху раньше думали, что ЮКОС это просто Юркие Комсомольцы, обогатившиеся Сибирью, а потом спохватились, что это могут быть Юные Капиталисты, Овладевающие Страной.

Слот 3.1.2. «Виды природных ресурсов». Представления о богатых залежах сибирских природных ресурсов репрезентируются как с помощью родовых номинаций (природные богатства, минеральные ресурсы, полезные ископаемые, месторождения и др.), так и с помощью их видовых наименований (уголь, газ, нефть, золото, самочветь и др.):

(39) Чтобы компенсировать потери от закрытия Черкизовского рынка в Москве, премьер-министр России Владимир Путин распорядился отдать Китаю минеральные ресурсы Сибири и Дальнего Востока.

(40) Лимузин врезается на перекрестке в Майбах, из лимузина выскакивает олигарх, а из Майбаха медленно, важной походкой выходит генерал ФСБ и говорит: «Ну, ты попал, мужик! Ладно. Собирайся, поедем в Сибирь, посмотрим НАШИ нефтяные месторождения. Заодно и колонию себе подберешь».

Слот 3.1.3. «Контроль над природными ресурсами Сибири». В юмористическом дискурсе активно обсуждаются притязания на Сибирь иностранных государств. В качестве претендентов на ее богатства в анекдотах регулярно называются США и Китай:

(41) Перед штурмом Багдада американские солдаты молятся.

- Господи, сделай так, чтобы в Тюмени закончилась нефть.

- Ты че?

- А тебе охота защищать демократию в холодной Сибири? тайцем

(42) Сидят в Хабаровске и пьют русский с ки-

(К): - Русских мало, а земли много!

(Р): - Ясен пень!

(К): - Сибирь вы освоить не можете!

(Р): - Ясен пень!

(К): - Сибирь мы у вас заберем!

(Р): - Ясен пень!

(К): - Почему все время «ясень пень»?!

(Р): - Ясен пень, фиг вы у нас получите!

Субфрейм 3.2. «Сельское хозяйство». Из-за суровых климатических условий Сибирь 


\section{РАЗВИТИЕ И ФУНКЦИОНИРОВАНИЕ РУССКОГО ЯЗЫКА}

стереотипно воспринимается как зона рискованного земледелия. Юмористический дискурс, казалось бы, опровергает тезис о непредсказуемости урожаев в подобных условиях, но фактически демонстрирует идею бессмысленности любой сельскохозяйственной деятельности в регионе:

(43) В Сибири никогда не бывает сюрпризов с урожаем картошки. Результат всегда предсказуем: сколько закопал - столько и выкопал.

\section{4. Фрейм “СОЦИАЛЬНАЯ СФЕРА»}

В юмористическом дискурсе Сибирь предстает как депрессивный регион, в котором практически нет никаких условий для жизни.

Субфрейм 4.1. «Социальные проблемы». Удаленность от столицы, суровые климатические условия и ряд иных факторов предопределяют формирование стереотипов о сложной и неустроенной жизни населения в Сибири.

Слот 4.1.1. «Голод». Юмористический дискурс транслирует стереотипные представления о голодающей Сибири, в которой все живое и неживое является пищей для местных жителей: дилов?

(44) - Папа, а почему в Сибири нет кроко-

- Голодно в Сибири.

- Думаешь, они не нашли бы там что покушать?

- Думаю, их там кто-нибудь бы скушал.

(45) В Сибири у людей культ мяса. У сибиряков все, что не бегает и не издает звуки, - это гарнир.

Слот 4.1.2. "Алкоголизм». Согласно стереотипным представлениям, низкие температуры вызывают у жителей Сибири регулярное желание согреться с помощью употребления спиртных напитков, соответственно, в анекдотах сибиряки показаны как постоянно находящиеся в состоянии алкогольного опьянения:

(46) - Я живу в Африке. У нас жарко. Пьем кофе, едим бананы, ходим голые.

- Я живу в Сибири. У нас холодно. Пьем водку. Если будем пить кофе и есть бананы, будем ходить голые.

(47) На съезде КПСС Брежнев читает телеграмму: Вот что пишут нам товарищи из Сибири: «Сроч- но пришлите две цистерны водки, зпт. Народ протрезвел и спрашивает, куда девали царя.

\section{Слот 4.1.3. «Проблемы со снабжени-}

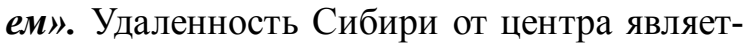
ся причиной формирования стереотипных представлений о существовании сибиряков в режиме самообеспечения:

(48) Иностранные корреспонденты (ИК) интервьюируют сибиряка.

(ИК): - Как у вас в Сибири с жильем?

(C):- Хорошо в Сибири с жильем. Леса много. Руби себе сколь хочешь и строй терема.

(ИК): - Как у вас в Сибири с питанием?

(C): - Хорошо в Сибири с питанием. Леса много, зверья в нем не считано. Завалишь, скажем, лося. Наделаешь пельменей. Ешь - не хочу!

(ИК): - Как у вас в Сибири с одеждой?

(C): - Хорошо в Сибири с одеждой. Я же говорил, зверья много. Бей соболя, куницу, бобра. Шей себе шубы и ходи как боярин.

(ИК): - Не могли бы вы назвать какие-либо негативные стороны жизни в Сибири?

(C): - Холодно, блин!

Субфрейм 4.2. «Неразвитая инфраструктура». Один из наиболее распространенных стереотипов, отраженных в юмористическом дискурсе, - это абсолютное отсутствие в Сибири дорог и нормального транспорта:

(49) - Так ты с Сибири? Говорят, у вас медведи по дорогам ходят? - Врут, нет у нас дорог.

(50) - Ты почему сегодня опоздал?

- Да пока поймал в тайге медведя, пока запряг в санки и отвез детей в школу, а то лошадь волки ночью сожрали..

В качестве транспортных средств, на которых можно перемещаться по Сибири, в анекдотах предстают танк, Камаз и тягач:

(51) - А надо было бы ВВП на танке Т-90, как в прошлый раз на желтой Калине, по Сибири проехаться! - Не годится. Там было три Калины: одна основная и две запасные. А Т-90 - всего в одном экземпляре.

(52) «Атлас автомобильных дорог Италии». Реклама на обложке: «Фиат Пунто».

«Автоатлас России от Калининграда до Урала». Реклама на обложке: «КАМАЗ».

«Атлас автомобильных дорог Сибири и Дальнего Востока». Реклама на обложке: «Седельный тягач "Урал"). 


\section{5. Фрей.м «НАСЕЛЕНИЕ»}

Достаточно противоречивыми в юмористическом дискурсе являются стереотипы, связанные с населением Сибири.

Субфрейм 5.1. «Малонаселенность». Обширное пространство, которое занимает рассматриваемый регион, сложно представить плотно заселенным людьми, что и рождает стереотипы об огромных безлюдных территориях, по которым можно идти месяцами и не встретить ни одной живой души:

(53) 2033 год. Началась война между Россией и США. Американские диверсанты в полной боевой амуниции уже месяц идут по Сибири. Уставший рядовой спрашивает у капрала:

- Капрал, мы уже месяц шагаем по Сибири и при этом никого не встретили, так?

- Да.

- Тогда, может, мы хоть снимем рекламу кокаколы с касок?

Малонаселенность Сибири связывается в анекдотах также с низкими температурами:

(54) Вот так, совершенно ненавязчиво, природа решает проблему заселения Сибири.

Субфрейм 5.2. «Жители Сибири». Согласно анекдотам жителями региона являются преимущественно ссыльные и мигранты, полностью вытеснившие коренное население.

Слот 5.2.1. "Ссыльные и мигранты». Как уже было видно в предыдущих фреймах и слотах, в Сибирь редко приезжают добровольно - большая часть населения оказалась здесь вынуждено:

(55) - Сидоров, скажите, где находится Сибирь? - В Азии.

- А каким путем туда проще всего попасть?

- Проще всего через суд.

(56) - Ты куда этим летом собираешься?

- Да, наверное, в Сибирь мотанусь.

- Тебе что, делать нечего?

- Я, в принципе, того же мнения, но прокурор настаивает!

(57) Богатство России будет прирастать Сибирью, а ее население, похоже, Северным Кавказом и Средней Азией.
Слот 5.2.2. «Китайцы». Относительно новые стереотипы связаны с активной миграцией китайцев в регион и обсуждением вопроса возможной передачи части сибирской территории Китаю. Юмористический дискурс активно эксплуатирует данные темы и создает стереотипный образ Сибири, в которой китайцы постепенно вытесняют местное население.

(58) Китай поддерживает Россию в ситуации с Крымом и напоминает, что в Сибири проживает 6 млн китайцев.

(59) Парадокс - русские не любят, когда в Сибири живут китайщы, но мечтают поселить туда прибалтов.

\section{Выводы}

Проведенный анализ позволил установить, что стереотипный образ Сибири репрезентирован в юмористическом дискурсе посредством фреймов «Природа и география», «История», «Экономика», «Социальная сфера» и «Население», тесно связанных между собой. В то же время в анекдотах отсутствуют стереотипы о Сибири, связанные с фреймами «Культура», «Наука», «Спорт». Такая организация стереотипного образа свидетельствует о том, что Сибирь воспринимается в первую очередь как регион, статус которого определяется объективно сложившимися обстоятельствами - географическим положением, размером, климатом и природными богатствами. Эти факторы также определили его историю, современное состояние экономики и социальной среды. Обстоятельства, формируемые целенаправленно (достижения в культуре, науке и спорте), пока не стали характеристиками узнаваемого образа Сибири. Для создания ее позитивного образа необходима серьезная работа в данном направлении.

Анализ также показал, что стереотипы о Сибири достаточно статичны, однако в медиадискурсе они являются динамичными. Анекдоты отражают традиционно существующие в сознании значительного количества людей (жителей других регионов России и иностранцев) стереотипные представления о Сибири как о далеком огромном регионе с суровыми климатическими условиями, богатом природными ресурсами сырьевом придатке 
России, месте ссылки и тяжелого труда вынужденных переселенцев. К относительно новым стереотипным признакам можно отнести лишь восприятие Сибири как объекта притязаний других стран.

Образ Сибири в юмористическом дискурсе достаточно депрессивен: большинство существующих стереотипов имеет ярко выраженный негативный характер (стереотипы 'далеко', 'холодно', ‘безлюдно', ‘голод’, 'нищета', 'отсутствие инфраструктуры', 'волки и медведи', 'лагеря и тюрьмы') и вызывает чувство тревожности.

Проведенное исследование продемонстрировало эффективность использования анекдотов для реконструкции стереотипного образа территории, позволило выявить негативные характеристики Сибирского региона, прочно укрепившиеся в сознании россиян. Это дает возможность начать работу по корректировке отрицательных представлений и эффективному выстраиванию работы при создании позитивного имиджа Сибири.

\section{ПРИМЕЧАНИЕ}

${ }^{1}$ Исследование выполнено при финансовой поддержке РФФИ и Администрации Кемеровской области, проект № 18-412-420003 p_а «Кузбасс: комплексное когнитивно-дискурсивное исследование образа региона».

The reported study was supported by grant № 18-412-420003 p_a “Kuzbass: Complex CognitiveDiscursive Study of the Regional Image" from the Russian Foundation for Basic Research and the government of Kemerovo oblast, Russian Federation.

\section{СПИСОК ЛИТЕРАТУРЫ}

Абильдинова Ж. Б., 2008. Стереотипные представления о русских, казахах и немцах в анекдотах // Вестник Казахского национального университета им. аль-Фараби. Серия филологическая. № 5 (113). С. 162-165.

Бартминьский Е., 2009. Базовые стереотипы и их профилирование (на материале польского языка) // Стереотипы в языке, коммуникации и культуре : сб. ст. / [сост. и отв. ред. Л. Л. Федорова]. М. : РГГУ. С. 11-21.

Жерновая О. Р., 2011. Этнокультурные стереотипы ирландцев в современных «антиирландских» шутках и анекдотах // Вестник Нижегородско- го государственного лингвистического университета им. Н.А. Добролюбова. № 15. С. 40-49.

Кондратьева О. Н., Фролова Т. И., 2018. Образ региона в обыденном языковом сознании его жителей (на примере образа Кузбасса) // Психолингвистика. Т. 24, №2. С. 78-97 . DOI: 10.31470/ 2309-1797-2018-24-2-78-96.

Крысько В. Г., 2008. Стереотип национальный (этнический) // Этнопсихологический словарь. М. : Академия. 320 c.

Маленова Е. Д., Терских М. В., 2015. Медиаобраз сибирского региона (по материалам современных американских СМИ) // Человек в мире культуры. № 3. С. 19-30.

Печищев И. М., 2007. Концепт «столица» как основание для конструирования образа территории (на материале пермских печатных СМИ) // Вестник Воронежского государственного университета. Серия: Филология. Журналистика. № 2. С. 201-204.

Собянина В. А., 2018. Языковая репрезентация этностереотипов в немецких анекдотах и шутках (на примере интернет-сайтов) // Известия Волгоградского педагогического университета. № 1 (124). С. 125-130.

Сушненкова И. А., 2011. Лингвокогнитивное моделирование как перспективный метод исследования регионального имиджа (на примере имиджа Омской области) // Вестник Омского университета. № 4 (62). С. 233-237.

Тер-Минасова С. Г., 2000. Язык и межкультурная коммуникация. М. : Слово. $624 \mathrm{c}$.

Шмелева Е. Я., Шмелев А. Д., 2014. Этнические стереотипы в русских анекдотах // Отечественные записки. № 4 (61). С. 167-177.

Lippman W., 1922. Public Opinion. N. Y. : The Free Press. $422 \mathrm{p}$.

Quasthoff U., 1973. Soziales Vorurteil und Kommunikation: Eine sprachwissenschaftliche Analyse des Stereotyps. Frankfurt a. M : Athenaum-Verlag. $312 \mathrm{~S}$.

\section{ИСТОЧНИКИ}

Анекдоты из России. URL: https://www.anekdot.ru. Анекдотов мир.py. URL: http://www.anekdotovmir.ru. Анекдотов.net. URL: http://anekdotov.net.

\section{REFERENCES}

Abildinova Zh.B., 2008. Stereotipnye predstavleniya o russkikh, kazakhakh i nemtsakh v anekdotakh [Stereotypical Ideas About Russians, Kazakhs and Germans in Jokes]. Vestnik Kazakhskogo 
natsionalnogo universiteta im. al-Farabi. Seriya filologicheskaya [KazNU Bulletin. Philology Series], no. 5 (113), pp. 162-165.

Bartminskiy E., 2009. Bazovye stereotipy i ikh profilirovanie [Base stereotypes and their profiling]. Stereotipy v yazyke, kommunikatsii $i$ kulture: sb. st. [Stereotypes in Language, Communications and Culture. Collected Articles]. Moscow, RGGU, pp. 11-21.

Zhernovaya O.R., 2011. Etnokulturnye stereotipy irlandtsev v sovremennykh «antiirlandskikh» shutkakh i anekdotakh [Ethnocultural Stereotypes of Irishmen in Contemporary English Anti-Irish Jokes and Funny Stories]. Vestnik Nizhegorodskogo gosudarstvennogo lingvisticheskogo universiteta im. N.A. Dobrolyubova [Vestnik of Nizhny Novgorod Linguistics University], no. 15, pp. 40-49.

Kondratyeva O.N., Frolova T.I., 2018. Obraz regiona v obydennom yazykovom soznanii ego zhiteley (na primere obraza Kuzbassa) [The Image of Region in Ordinary Language Consciousness of Its Residents (On an Example of an Image of Kuzbass)]. Psycholinguistics, vol. 24, no. 2, pp. 7897. DOI: 10.31470/2309-1797-2018-24-2-78-96.

Krysko V.G., 2008. Stereotip natsionalnyy (etnicheskiy) [National (Ethnic) Stereotype]. Etnopsikhologicheskiy slovar [Ethnopsychological Dictionary]. Moscow, Akademiya Publ. 320 p.

Malenova E.D., Terskikh M.V., 2015. Mediaobraz sibirskogo regiona (po materialam sovremennykh amerikanskikh SMI [Media-Image of Siberian Region (Based on Analysis of the Modern American Media]. Chelovek v mire kultury, no. 3, pp. 19-30.

Pechishchev I.M., 2007. Kontsept «stolitsa» kak osnovanie dlya konstruirovaniya obraza territorii (na materiale permskikh pechatnykh SMI) [Concept "Capital" as a Basis for Constructing Image of the Territory (On a Material of the Perm Printed Mass-Media)]. Vestnik Voronezhskogo gosudarstvennogo universiteta. Seriya: Filologiya. Zhurnalistika [Proceedings of Voronezh State University. Series: Philology. Journalism], no. 2, pp. 201-204.

Sobyanina V.A., 2018. Yazykovaya reprezentatsiya etnostereotipov $\mathrm{v}$ nemetskikh anekdotakh i shutkakh (na primere internet-saytov) [Linguistic Representation of Ethnic Stereotypes in German Anecdotes and Jokes (Based on Internet Websites)]. Izvestiya Volgogradskogo pedagogicheskogo universiteta [Izvestiya of the Volgograd State Pedagogical University], no. 1 (124), pp. 125-130.

Sushnenkova I.A., 2011. Lingvokognitivnoe modelirovanie kak perspektivnyy metod issledovaniya regionalnogo imidzha (na primere imidzha Omskoy oblasti) [Cognitive-Linguistic Modeling as a Perspective Method of Research of Regional Image (By Example of Image of Omsk Region)]. Vestnik Omskogo universiteta [Herald of Omsk University], no. 4 (62), pp. 233-237.

Ter-Minasova S.G., 2000. Yazyk i mezhkulturnaya kommunikatsiya [Language and the Intercultural Communications]. Moscow, Slovo Publ. 624 p.

Shmeleva E.Ya., ShmelevA.D., 2014. Etnicheskie stereotipy $\mathrm{v}$ russkikh anekdotakh [Ethnic Stereotypes in Russian Anecdotes]. Otechestvennye zapiski [Domestic Notes], no. 4 (61), pp. 167-177.

Lippman W., 1922. Public Opinion. New York, The Free Press. 422 p.

Quasthoff U., 1973. Soziales Vorurteil und Kommunikation: Eine sprachwissenschaftiche Analyse des Stereotyps. Frankfurt am Main, Athenaum-Verlag. $312 \mathrm{~S}$.

\section{SOURCES}

Anekdoty iz Rossii [Jokes from Russia]. URL: https:// www.anekdot.ru.

Anekdotov mir.ru. URL: http://www.anekdotovmir.ru. Anekdotov.net. URL: http://anekdotov.net.

\section{Information about the Author}

Olga N. Kondratyeva, Doctor of Sciences (Philology), Associate Professor, Professor, Department of Russian Language, Kemerovo State University, Krasnaya St., 6, 650000 Kemerovo, Russia, Kondr25@rambler.ru, Olnik25@mail.ru, https://orcid.org/0000-0001-9469-3634

\section{Информация об авторе}

Ольга Николаевна Кондратьева, доктор филологических наук, доцент, профессор кафедры русского языка, Кемеровский государственный университет, ул. Красная, 6, 650000 г. Кемерово, Россия, Kondr25@rambler.ru, Olnik25@mail.ru, https://orcid.org/0000-0001-9469-3634 